\title{
Pengaruh Dana Desa Terhadap Pembangunan Desa di Kecamatan Siantar Narumonda melalui Pemberdayaan Masyarakat
}

Artha Lumban Tobing1, Ridhon Simangunsong², Nalom Siagian ${ }^{3}$

${ }^{1}$ Program Studi Administrasi Publik Fakultas Ilmu Sosial dan Ilmu Politik Universitas HKBP Nommensen Medan 2,3Program Studi Administrasi Bisnis Fakultas Ilmu Sosial dan Ilmu Politik Universitas HKBP Nommensen Medan Jl. Sutomo No.4A, Perintis, Kec. Medan Tim., Kota Medan, Sumatera Utara 20235

E-mail: arthalombangt@gmail.com

\begin{tabular}{l}
\hline Article Info \\
\hline Article History \\
Received: $2021-11-15$ \\
Revised: 2021-11-28 \\
Published: $2021-12-12$
\end{tabular}

Keywords: Village funds; Empowerment; Public;

Development.

\begin{abstract}
The object of this research to known rural fund management affected on rural development at Siantar Narumonda District, Toba Regency, in directly and by community empowerment as intervening variable. The population in this study were people who were scattered in all villages in Siantar Narumonda District, Toba Regency were 6,032 people. The sample in this research were 210 respondents who were taken by proportional random sampling. The data collected in this research were analyzed using path regression analysis. Based on the results of the analysis, concluded that rural funds have a significant negative effect on rual development, while on community empowerment, rural funds have a significant positive effect, and community empowerment has a significant positive effect on rural development. Rural funds will have a significant positive effect on rural development, if by community empowerment as intervention variable.
\end{abstract}

\begin{tabular}{l}
\hline Artikel Info \\
\hline Sejarah Artikel \\
Diterima: $2021-11-15$ \\
Direvisi: $2021-11-28$ \\
Dipublikasi: $2021-12-12$
\end{tabular}

Kata kunci:

Dana desa;

Pemberdayaan;

Masyarakat;

Pembangunan.

\begin{abstract}
Abstrak
Penelitian ini bertujuan untuk mengetahui sekaligus menganalisis pengaruh pengelolaan dana desa terhadap pembangunan desa di Kecamatan Siantar Narumonda Kabupaten Toba, baik secara langsung muapun melalui pemberdayaan masyarakat. Populasi dalam penelitian ini masyarakat yang tersebar seluruh Desa di Kecamatan Siantar Narumonda Kabupaten Toba sebanyak 6.032 jiwa. Sampel dalam penelitian ini sebanyak sampel 210 responden yang diambil secara proportional random sampling. Data yang terkumpul dalam penelitian ini dianalisis dengan menggunakan analisis regresi jalur. Berdasarkan hasil analisis, disimpulkan bahwa dana desa berpengaruh negatif signifikan terhadap pembangunan desa, sedangkan terhadap pemberdayaan masyarakat, dana desa berpengaruh positif signifikan dan pemberdayaan masyarakat berpengaruh positif signifikan terhadap pembangunan desa. Dana desa akan berpengaruh positif signifikan terhadap pembangunan desa, jika melalui pemberdayaan masyarakat sebagai variabel intervening.
\end{abstract}

\section{PENDAHULUAN}

UU No. 32 Tahun 2004 tentang Pemerintahan Daerah memberikan keleluasaan penuh bagi daerah didalam menjalankan prinsip-prinsip demokrasi, peran serta masyarakat, pemerataan, keadilan serta dengan memperhatikan potensi dan keanekaragaman daerah. UU ini menjadi landasan hukum bagi tiap daerah untuk mengatur dan mengurus kepentingan masyarakat setempat menurut prakarsa sendiri berdasarkan aspirasi masyarakat. Masyarakat diberi peran yang lebih besar dalam pembangunan daerah. Dimana pembangunan daerah itu sendiri merupakan bagian yang tidak bisa dipisahkan dari pembangunan desa, mengingat kosentrasi jumlah penduduk masih dominan berada di daerah desa, sehingga desa merupakan basis kekuatan sosial ekonomi dan politik yang perlu mendapat perhatian serius dari pemerintah.

Permendesa Pembangunan Daerah Tertinggal, dan Transmigrasi Nomor 16 tahun 2018 tentang perioritas penggunaan dana desa tahun 2019 mengatakan bahwa pembangunan desa merupakan suatu upaya yang dilakukan oleh pemerintah desa maupun masyarakatnya untuk meningkatkan kualitas hidup dalam kesejahteraan masyarakat desa. Adapun yang menjadi tujuan dari pembangunan desa menurut pasal 78 UU No 6 Tahun 2016 tentang Desa adalah untuk meningkatkan kesejahteraan dan kualitas hidup masyarakat desa, serta penanggulangan kemiskinan melalui pemenuhan kebutuhan dasar, pembangunan sarana dan prasarana desa, pengembangan potensi ekonomi lokal, serta pemanfaatan sumber daya alam dan lingkungan secara berkelanjutan. Mulyanto (2013) menyebutkan 
terdapat 9 (sembilan) indikator didalam mengukur kemajuan pembanguan suatu desa, yaitu : 1) kapasitas aparatur dan jangkauan pelayanan publik; 2) kekayaan dan keuangan Desa; 3) sarana perekonomian Desa; 4) sarana transportasi dan telekomunikasi; 5) kelembagaan dan partisipasi masyarakat Desa, 6) Kesejahteraan Masyarakat; 7) Pendidikan Masyarakat; 8) kesehatan masyarakat, dan 9) kesejahteraan keluarga.

Kessa (2015) menyebutkan 4 (empat) bidang pembangunan desa, salah satu diantaranya adalah pemberdayaan masyarakat desa. Pemberdayaan Masyarakat pada dasarnya adalah suatu proses pertumbuhan dan perkembangan kekuatan masyarakat untuk ikut terlibat dalam berbagai aspek pembangunan, baik pembangunan nasional, daerah maupun pembangunan desa. Suharto (2014) mengatakan pemberdayaan masyarakat merupakan kemampuan orang, khususnya kelompok rentan dan lemah sehingga mereka memiliki kekuatan atau kemampuan dalam (a) memenuhi kebutuhan dasarnya sehingga mereka memiliki kebebasan (freedom), dalam arti bukan saja bebas mengemukakan pendapat, melainkan bebas dari kelaparan, bebas dari kebodohan, bebas dari kesakitan; (b) menjangkau sumber-sumber produktif yang memungkinkan mereka dapat meningkatkan pendapatannya dan memperoleh barang-barang dan jasa-jasa yang mereka perlukan; dan (c) berpartisipasi dalam proses pembangunan dan keputusan-keputusan yang mempengaruhi mereka. Dengan pemberdayaan masyrakat diharapkan yang tadinya masyarakat tidak berdaya menjadi berdaya, baik secara personal, kelompok maupun dalam pembangunan desa. Pasal 6 Peraturan Menteri Dalam Negeri No.114 Tahun 2014 menyebutkan aspek pemberdayaan masyarakat desa meliputi : 1) pelatihan usaha, 2) pelatihan teknologi, 3) diklat dan penyuluhan bagi kepala Desa, perangkat Desa, dan Badan Pemusyawaratan Desa; serta 4) peningkatan kapasitas masyarakat.

Sebagai bentuk dukungan atas pelaksanaan tugas dan fungsi desa dalam pembangunan desa sesuai dengan kewenangan yang dimiliki, UU Nomor 6 Tahun 2014 memberikan wewenang kepada Pemerintah untuk mengalokasikan Dana Desa. Dana Desa tersebut dianggarkan setiap tahun dalam APBN yang diberikan kepada setiap desa sebagai salah satu sumber pendapatan desa yang ditujukan untuk meningkatkan pelayanan publik di desa, mengentaskan kemiskinan, memajukan perekonomian desa, mengatasi kesenjangan pembangunan antar desa serta memberdayakan masyarakat desa sebagai subjek dari pembangunan desa. Peraturan Menteri Desa (2016) mengatakan bahwa dana desa adalah dana yang bersumber dari anggaran pendapatan dan belanja negara yang diperuntukkan bagi desa yang ditransfer melalui anggaran pendapatan dan belanja daerah kabupaten/kota dan digunakan untuk membiayai penyelenggaraan pemerintahan desa, pelaksanaan pembangunan desa, pembinaan kemasyarakatan desa, dan pemberdayaan masyarakat desa. Permendesa Pembangunan Daerah Tertinggal, dan Transmigrasi Nomor 16 tahun 2018 tentang perioritas penggunaan dana desa tahun 2019 menyebutkan prioritas peggunaan dana desa dilengkapi dengan pedoman umum pelaksanaan penggunaan dana desa yang berlandaskan pada asas pengelolaan keuangan desa yang transparan, akuntanbel, partisipatif, tertib dan disiplin anggaran.

Berbicara tentang pembangun desa erat kaitannya dengan pemberdayaan masyarakat dan dana desa. Muslihah, dkk (2019) dalam penelitiannya memberikan bukti empiris bahwa pemberian Dana desa oleh pemerintah memberikan dampak terhadap pembangunan fisik. Rimawan \& Aryani (2019) menyebutkan semakin tinggi dana desa yang disediakan, semakin tinggi tingkat pembangunan desa. Berbeda dengan Jamaluddin (2018) yang dalam peneleitiannya yang justeru menemukan bahwa pengelolaan dan penggunaan Dana Desa tidak memberi dampak signifikan bagi pertumbuhan pembangunan daerah dan program pembangunan Desa tidak sinkron dengan kebijakan pembangunan Daerah (RPJM Daerah)

Fathony dan Sopian (2019) dalam penelitiannya menemukan bahwa Alokasi Dana Desa memberikan pengaruh yang positif dan signifikan terhadap Pemberdayaan Masyarakat. Bili dan Ra'is (2017) dalam penelitiannya memberikan bukti empiris dengan adanya anggaran Dana Desa sudah memberikan dampak positif terhadap masyarakat terutama pemberdayaan masyarakat.

Sofianto (2017) dalam penelitiannya memberikan bukti empiris bahwa pelaksanaan dana desa memberikan sumbangan berupa meningkatnya aksesibilitas masyarakat desa dan partisipasi masyarakat dalam pembangunan. Fatah, dkk (2018) menemukan bahwa dampak dana desa dalam pemberdayaan masyarakat bermanfaat dalam mengggerakkan kegiatan ekonomi berbasis rumah tangga dalam pengelolaan, 
produksi dan distribusi. Dampak Dana Desa bagi Pemerintah Desa dapat meberikan percepatan pembangunan desa dalam rangka mencapai visi dan misi pemerintah desa yang ada dalam RPJMDes. Firmansyah, dkk (2020) menemukan bahwa pengelolaan dan penyaluran dana desa yang tepat sasaran dapat memberikan dampak pengaruh terhadap kemajuan pembangunan desa dan pemberdayaan masyarakat desa sehingga mampu mendorong berkembangnya kemandirian masyarakat.

Berdasarkan uraian latar belakang masalah di atas, dirumuskan permasalahan yang akan dikaji dalam penelitian ini kedalam bentuk pertanyaan kuantitatif : 1) Apakah terdapat pengaruh dana desa terhadap pemberdayaan masyarakat dan pembangunan desa di Kecamatan Siantar Narumonda Kabupaten Toba?, 2) Apakah terdapat pengaruh pemberdayaan masyarakat terhadap pembangunan desa di Kecamatan Saintar Narumonda Kabupaten Toba?, dan 3) Apakah terdapat pengaruh dana desa terhadap pembangunan desa di Kecamatan Siantar Narumonda melalui pemberdayaan masyarakat? Penelitian ini dilakukan dengan tujuan untuk mengetahui dan menganalisis : 1) pengaruh dana desa terhadap pemberdayaan masyarakat dan pembangunan desa di Kecamatan Siantar Narumonda Kabupaten Toba; 2) pengaruh pemberdayaan masyarakat terhadap pembangunan desa di Kecamatan Saintar Narumonda Kabupaten Toba, dan 3) pengaruh dana desa terhadap pembangunan desa di Kecamatan Siantar Narumonda melalui pemberdayaan masyarakat. Dari permasalahan yang dirumuskan dalam penelitian ini, dibangun hipotesis-1 (H1) dalam penelitian ini : Terdapat pengaruh dana desa terhadap pemberdayaan masyarakat dan pembangunan desa di Kecamatan Siantar Narumonda Kabupaten Toba, H2 : Terdapat pengaruh pemberdayaan masyarakat terhadap pembangunan desa di Kecamatan Saintar Narumonda Kabupaten Toba, dan H3 : Terdapat pengaruh dana desa terhadap pembangunan desa di Kecamatan Siantar Narumonda melalui pemberdayaan masyarakat.

\section{METODE PENELITIAN}

A. Jenis penelitian

Penelitian ini menggunakan jenis penelitian explanatory research, karena penelitian ini menjelaskan hubungan causal antara variabelvariabel melalui pengujian hipotesis atau penelitian penjelasan. Metode yang digunakan dalam penelitian ini metode kuantitatif, yaitu metode penelitian yang berlandaskan pada filsafat positivisme, digunakan untuk meneliti pada populasi atau sampel tertentu, teknik sampling dilakukan secara random, data dikumpulkan melalui instrumen penelitian, dan data dianalisis secara kuantitatif/statistik untuk menguji hipotesis yang diteliti (Sugiyono, 2007). Penelitian kuantitatif dalam penelitian dilakukan terhadap data survei kuesioner, berdimensi hubungan variabel causal effect (sebab akibat).

B. Waktu dan tempat penelitian

Penelitian ini dilakukan dari bulan Juli 2020 hingga Desember 2020. Penelitian dilakukan pada 14 (empat belas) Desa yang tersebar di Kecamatan Siantar Narumonda Kabupaten Toba.

\section{Operasional Variabel}

Variabel bebas dalam penelitian ini adalah dana desa (X1), variabel interveningnya pemberdayaan masyarakat (X2) dan variabel terikatnya adalah pembangunan desa (Y). Secara operasional, dana desa dalam penelitian ini adalah dana yang disiapkan pemerintah pusat untuk membiayai penyelenggaraan pemerintah desa untuk pemberdayaan masyarakat dan pembangunan desa. Dana desa harus dikelola secara transparan, akuntanbel, partisipatif, tertib dan disiplin anggaran. Pemberdayaan masyarakat desa dimaksud dalam penelitian ini adalah upaya upaya yang dilakukan pemerintah desa didalam melepaskan masyarakatnya dari ketidakberdayaan menjadi berdaya dengan melakukan pelatihan usaha, pelatihan teknologi, diklat dan penyuluhan serta peningkatan kapasitas masyarakat. Secara operasi-onal, pembangunan desa adalah upaya - upaya yang dilakukan pemerintah desa didalam meningkatkan taraf hidup masyarakatnya. Indikator pembangunan suatu desa dapat dilihat dari: kapasitas aparatur dan jangkauan pelayanan publik; kekayaan dan keuangan desa; sarana perekonomian desa; sarana transportasi dan telekomunikasi; kelembagaan dan partisipasi masyarakat desa, kesejahteraan masyarakat; pendidikan masyarakat; kesehatan masyarakat, dan kesejahteraan keluarga.

\section{Populasi dan Sampel}

Populasi dalam penelitian adalah masyarakat Kecamatan Siantar Narumonda dengan jumlah penduduk mencapai 6.032 jiwa yang tersebar di 14 Desa. Dengan keterbatasan dari 
segi waktu, tenaga dan materi, maka dilakukan penarikan sampel. Ferdinand (2006) menyatakan bila ukuran sampel terlalu besar maka model menjadi sangat sensitif sehingga sulit untuk mendapatkan hasil yang baik. Untuk itu disarankan ukuran sampel adalah 510 kali jumlah variabel manifest dari seluruh variabel laten, selanjutnya ditentukan jumlah sampel dalam penelitian ini, $\mathrm{n}=10 \mathrm{x}$ (jumlah variabel laten + jumlah variabel indikator $)=$ $10 \times$ (3variabel laten +18 variabel indikator) $=$ 210. Sampel dalam penelitian ini diambil dengan menggunakan pendekatan proportional random sampling. Penggunaan metode ini dilakukan agar setiap populasi memiliki keterwakilan dan kesempatan yang sama menjadi sampel penelitian.

\section{E. Teknik Pengumpulan data}

Jenis data digunakan dalam penelitian ini adalah data primer, yaitu data yang bersumber dari responden penelitian. Data dalam penelitian ini dikumpulkan dengan menggunakan teknik kuesioner. Data terkumpul selanjutnya diolah dengan pendekatan kuantitatif dengan terlebih dahulu dilakukan tabulasi dan memberikan nilai sesuai dengan sistem yang ditetapkan. Jenis kuesioner yang digunakan adalah kuesioner tertutup dengan menggunakan skala ordinal. Untuk teknik perhitungan data kuesioner yang telah diisi oleh responden digunakan skala Likert 1 - 5, dimana skala 1 menunjukkan sangat tidak baik, dan skala 5 menunjukkan sangat baik.

\section{F. Teknik analisis data}

Data dalam penelitian ini dianalsis dengan menggunakan analisis SEM (structure equation model)/model persamaan berstruktur yang dihasilkan dari path regression analysis SPSS. Waluyo (2011) mengatakan penggunaan analisis SEM sangat memungkinkan digunakan untuk pengujian sebuah rangkaian hubungan yang relatif rumit secara simultan.

\section{G. Pengujian Hipotesis}

Hopotesis dalam penelitian ini diuji dengan menggunakn uji $t$ yang dihasilkan dari Coeffiecient2 output SPSS dan sobel test. Ghozali (2013) mengatakan suatu hipotesis diterima apabila memiliki $\mathrm{t}$ hitung $>\mathrm{t}$ tabel atau probabilitasnya lebih kecil dari 5\%.

\section{HASIL DAN PEMBAHASAN}

\section{A. Hasil Penelitian}

1) Analisis Statistik Deskriptif
Hasil analisis statistik deskriptif dalam penelitian ini dirangkum dalam Tabel 1 .

Tabel 1. Hasil Analisis Statistik Deskriptif

\begin{tabular}{|c|c|c|c|c|}
\hline Var & Indikator & $\begin{array}{c}\text { Mo } \\
\text { d }\end{array}$ & $\begin{array}{l}\text { Rata- } \\
\text { rata }\end{array}$ & $\begin{array}{c}\text { St. } \\
\text { Dev }\end{array}$ \\
\hline \multirow{9}{*}{ 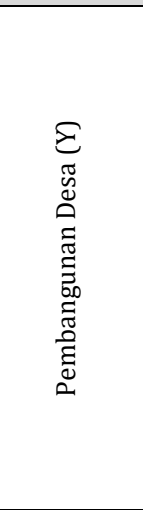 } & $\begin{array}{l}\text { Kapasitas aparatur desa } \\
\text { dalam layanan publik }\end{array}$ & 4 & 3,83 & 1,30 \\
\hline & $\begin{array}{l}\text { Kemampuan keuangan } \\
\text { desa }\end{array}$ & 4 & 3,99 & 1,34 \\
\hline & $\begin{array}{l}\text { Sarana perekonomian } \\
\text { desa }\end{array}$ & 3 & 3,12 & 1,34 \\
\hline & $\begin{array}{l}\text { Sarana transportasi dan } \\
\text { komunikasi }\end{array}$ & 4 & 3,92 & 1,32 \\
\hline & $\begin{array}{l}\text { Kelembagaan partisipasi } \\
\text { masyarakat }\end{array}$ & 4 & 3,91 & 1,42 \\
\hline & $\begin{array}{l}\text { Kesejahteraan } \\
\text { masyarakat }\end{array}$ & 3 & 3,00 & 1,45 \\
\hline & Pendidikan masyarakat & 4 & 3,99 & 1,51 \\
\hline & Kesehatan masyarakat & 5 & 3,96 & 1,62 \\
\hline & Kesejahteraan keluarga & 5 & 3,13 & 1,44 \\
\hline \multirow{5}{*}{ 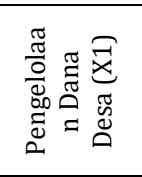 } & Transparan & 3 & 3,59 & 1,32 \\
\hline & Akuntabel & 4 & 3,74 & 1,42 \\
\hline & Partisipatif & 4 & 3,68 & 1,46 \\
\hline & Tertib anggaran & 4 & 3,67 & 1,33 \\
\hline & Disiplin anggaran & 3 & 3,69 & 1,47 \\
\hline \multirow{4}{*}{ 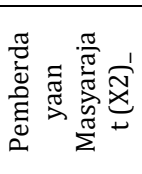 } & Pelatihan usaha & 3 & 3,69 & 1,25 \\
\hline & Pelatihan teknologi & 3 & 3,69 & 1,34 \\
\hline & Diklat dan Penyuluhan & 4 & 3,73 & 1,24 \\
\hline & $\begin{array}{l}\text { Peningkatan kapasitas } \\
\text { masyarakat }\end{array}$ & 3 & 3,58 & 1,41 \\
\hline
\end{tabular}

Sumber : Survei kuesioner (2020)

Tabel diatas, mendeskripsikan bahwa pembangunan desa di Kecamatan Narumonda Kabupaten Toba telah berlangsung dengan baik. Deskripsi ini terlihat dari nilai modus jawaban responden pada masing - masing indikator pembangunan desa yang berada diantara kisaran jawaban berbobot 3 (cukup baik), 4 (baik) dan 5 (sangat baik). Deskripsi ini juga dikuatkan dengan rata - rata skor jawaban responden atas indikator pembangunan desa, yaitu kapasitas aparatur desa dalam layanan publik sebesar 3,83 dengan standar deviasi 1,30; rata - rata skor jawaban responden atas indikator keuangan desa sebesar 3,99 dengan standar deviasi 1,34; sarana perekonomian desa sebesar 3,12 dengan standar deviasi 1,34; sarana perekonomian desa sebesar 3,12 dengan standar deviasi 1,34; sarana transportasi dan komunikasi sebesar 3,92 dengan standar deviasi 1,32; kelembagaan partisipasi masyarakat sebesar 3,91 dengan standar deviasi 1,42; kesejahteraan masyarakat sebesar 3,00 dengan standar deviasi 1,32; pendidikan masyarakat sebesar 3,99 dengan standar deviasi 1,51; kesehatan masyarakat sebesar 3,96 dengan standar deviasi 1,62 dan kesejahteraan keluarga sebesar 3,13 dengan standar devasi 1,44. 
Dana desa di Kecamatan Narumonda Kabupaten Toba juga telah dikelola dengan baik. Deskripsi ini terlihat dari nilai modus jawaban responden pada masing - masing indikator pengelolaan dana desa yang berada diantara kisaran jawaban berbobot 3 (cukup baik) dan 4 (baik). Deskripsi ini juga dikuatkan dengan rata - rata skor jawaban responden atas indikator pengelolaan dana desa, yaitu transparansi pengelolaan sebesar 3,59 dengan standar deviasi 1,32; rata - rata skor jawaban responden atas indikator akutabilias pengelolaan sebesar 3,74 dengan standar deviasi 1,42; partisipasi pengelolaan sebesar 3,68 dengan standar deviasi 1,46; tertib anggaran sebesar 3,67 dengan standar deviasi 1,33 dan rata - rata skor jawaban responden atas disiplin pengelolaan anggaran sebesar 3,69 dengan standar deviasi 1,47.

Pemberdayaan masyarakat di Kecamatan Narumonda Kabupaten Toba juga telah terlaksana dengan baik. Deskripsi ini terlihat dari nilai modus jawaban responden pada masing - masing indikator pemberdayaan masyarakat yang berada diantara kisaran jawaban berbobot 3 (cukup baik) dan 4 (baik). Deskripsi ini juga dikuatkan dengan rata rata skor jawaban responden atas indikator pengelolaan dana desa, yaitu pelatihan usaha sebesar 3,69 dengan standar deviasi 1,25; rata - rata skor jawaban responden atas indikator pelatihan teknologi sebesar 3,69 dengan standar deviasi 1,34; diklat dan penyuluhan sebesar sebesar 3,73 dengan standar deviasi 1,24; dan rata - rata skor jawaban responden atas indikator peningkatan kapasitas masyarakat sebesar 3,58 dengan standar deviasi 1,41 .

\section{2) Analisis Regresi Jalur}

Hasil analisis regresi dalam penelitian ini ditunjukkan pada Tabel 2 dan 3 berikut ini.

Tabel 2. Hasil Analisis Regresi Jalur Pengaruh Langsung Dana Desa dan Pemberdayaan Masyarakat terhadap Pembangunan Desa.

\begin{tabular}{|c|c|c|c|c|}
\hline \multicolumn{5}{|l|}{ Coefficients $^{a}$} \\
\hline \multirow[b]{2}{*}{ Model } & \multicolumn{2}{|c|}{$\begin{array}{l}\text { Unstandardized } \\
\text { Coefficients }\end{array}$} & \multirow[b]{2}{*}{$\mathrm{t}$} & \multirow[b]{2}{*}{ Sig. } \\
\hline & $\mathrm{B}$ & Std. Error & & \\
\hline (Constant) & 21,302 & 1,997 & 10,666 & 000 \\
\hline $\begin{array}{l}\text { Pengelolaan Dana } \\
\text { Desa }\end{array}$ &,- 504 & ,106 & $-4,740$ & ,000 \\
\hline $\begin{array}{l}\text { Pemberdayaan } \\
\text { Masarakat }\end{array}$ & 1,156 & ,151 & 7,643 & ,000 \\
\hline \multicolumn{5}{|c|}{ a. Dependent Variable: Pembangunan Desa } \\
\hline Model Summaryb & & & & \\
\hline
\end{tabular}

\begin{tabular}{lll}
\hline Model $\quad$ Adjusted R Square & $\begin{array}{l}\text { Std. Error of the } \\
\text { Estimate }\end{array}$ \\
\hline $1 \quad 238$ & 9,71981 \\
\hline $\begin{array}{l}\text { a. Predictors: (Constant), Pemberdayaan Masarakat, } \\
\text { Pengelolaan Dana Desa }\end{array}$ \\
\multicolumn{2}{l}{ b. Dependent Variable: Pembangunan Desa }
\end{tabular}

Sumber : Olahan Peneliti (2020)

Tabel 3. Hasil Analisis Regresi Jalur Pengaruh Langsung Dana Desa terhadap Pemberdayaan Masyarakat.

\begin{tabular}{lllll}
\hline Coefficients & \multicolumn{4}{l}{} \\
\hline & \multicolumn{4}{l}{$\begin{array}{l}\text { Unstandardized } \\
\text { Coefficients }\end{array}$} \\
\cline { 2 - 4 } Model & $\mathrm{B}$ & Error & $\mathrm{t}$ & Sig. \\
\hline (Constant) & 8,403 &, 706 & 11,904 &, 000 \\
\hline Pengelolaan Dana Desa &, 168 &, 047 & 3,546 &, 000 \\
\hline
\end{tabular}

a. Dependent Variable: Pemberdayaan Masarakat

\section{Model Summary}

\begin{tabular}{lll} 
Model & Adjusted R Square & $\begin{array}{l}\text { Std. Error of the } \\
\text { Estimate }\end{array}$ \\
\hline 1 &, 052 & 4,45475
\end{tabular}

a. Predictors: (Constant), Pengelolaan Dana Desa Sumber : Olahan Peneliti (2020)

Berdasarkan Tabel 2 dan 3 digambarkan diagram analisis regresi jalar dalam penelitian ini sebagai berikut:

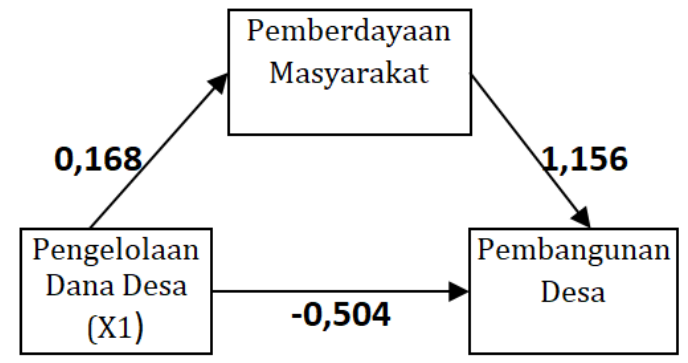

Gambar 1. Diagram Regresi Jalur Hubungan Pengelolaan Dana Desa, Pemberdayaan

Masyarakat dan Pembangunan Desa Sumber : Data Olahan Peneliti (2020)

Berdasarkan Tabel 2, Tabel 3 dan Gambar 1 , secara matematis diformulasikan persamaan regresi jalur dalam penelitian ini: Struktur Persamaan Langsung :

$Y=-0,504 X_{1}+1,156 X_{2}+9,72$. $X_{2}=0,168 X_{1}+4,45$

Struktur Persamaan Tidak Langsung

$Y=|0,168 * 1,156| X_{1}+9,72$

$\mathrm{Y}=0,194 \mathrm{X}_{1}+9,72$

Secara langsung pengelolaan dana desa diestimasi berpengaruh negatif sebesar 0,504 terhadap pembangunan desa di Kecamatan Narumonda Kabupaten Toba. Pemberdayaan 
masyarakat diestimasi berpengaruh positif sebesar 1,156 terhadap pembangunan desa. Kesalahan estimasi persamaan ini sebesar 9.72. Kekuatan variabel pengelolaan dana desa dan pemberdayaan masyarakat didalam menjelaskan pembangunan desa berdasarkan nilai adjusted $R$ sguare dalam penelitian ini sebesar $23,80 \%$, sedangkan sisanya sebesar 76,20\% lagi pembangunan desa di Kecamatan Siantar Narumonda Kabupaten Toba dipengaruhi oleh variabel lain selain pengelolaan dana desa dan pemberdayaan masyarakat yang belum diungkap dalam penelitian ini.

Secara langsung pengelolaan dana desa diestimasi berpengaruh positif sebesar 0,168 terhadap pemberdayaan masyarakat di Kecamatan Narumoda Kabupaten Toba, dengan nilai kesalahan estimasi sebesar 4,45. Kekuatan variabel pengelolaan dana desa didalam menjelaskan pemberdayaan masyarakat berdasarkan nilai adjusted $R$ sguare sebesar $5,20 \%$, sedangkan sisanya sebesar $94,80 \%$ lagi pemberdayaan masyarakat dipengaruhi oleh variabel lain selain pengelolaan dana desa yang belum diungkap dalam penelitian ini.

\section{3) Pengujian Hipotesis}

Hasil pengujian hipotesis dalam penelitian ini dirangkum dalam Tabel 4 berikut ini.

Tabel 4. Hasil Pengujian Hipotesis

\begin{tabular}{|c|c|c|c|c|}
\hline \multicolumn{2}{|c|}{ Variabel Penelitian } & \multicolumn{2}{|c|}{ Direct Effect } & Inderect Efect \\
\hline Terikat & Bebas & $\begin{array}{l}\mathrm{t} \text { hitung } \\
\text { (Prob) }\end{array}$ & Kriteria & thitung Kriteria \\
\hline $\begin{array}{l}\text { Pembangunan } \\
\text { desa } \\
\text { (Y) }\end{array}$ & $\begin{array}{l}\text { Pengelolaan } \\
\text { Dana Desa } \\
\text { (X1) }\end{array}$ & $\begin{array}{l}-4,740 \\
(0,000)\end{array}$ & $\begin{array}{l}\text { thitung }<\mathrm{t} \\
\text { tabel } 1210 \alpha \\
5 \% \text { dan prob } \\
0,00<\alpha 5 \% \\
\text { H1 Ditolak } \\
\text { (Negatif) }\end{array}$ & $\begin{array}{l}\text { thitung }>\text { t tabel dan prob } \alpha 0,000 \\
<5 \% \\
\text { H4 Diterima }\end{array}$ \\
\hline & $\begin{array}{l}\text { Pemberdayaan } \\
\text { Masyarakat } \\
\text { (X2) }\end{array}$ & $\begin{array}{c}7,6433 \\
(0,000)\end{array}$ & $\begin{array}{l}\text { t hitung }>t \\
\text { tabel } \mathrm{n} 210 \alpha \\
5 \% \text { dan prob } \\
0,000<\alpha 5 \% \\
\text { H2 Diterima }\end{array}$ & $\begin{array}{l}\text { Catatan: } \\
\mathrm{t} \text { tabel } \mathrm{n} 210 \propto 5 \%=1,652 \\
\text { Rumus Sobel Test (Sobel, 1982): } \\
\quad p 1 p 2\end{array}$ \\
\hline \multirow[t]{2}{*}{$\begin{array}{l}\text { Pemberdayaan } \\
\text { Masyarakat } \\
\text { (X2) }\end{array}$} & $\begin{array}{l}\text { Pengelolaan } \\
\text { Dana Desa } \\
\text { (X1) }\end{array}$ & $\begin{array}{c}3,546 \\
(0,000)\end{array}$ & $\begin{array}{l}\text { thitung }>t \\
\text { tabel } \mathrm{n} 210 \alpha \\
5 \% \text { dan prob } \\
0,000<\alpha 5 \% \\
\text { H3 Diterima }\end{array}$ & $\begin{array}{l}t / C R=\frac{P_{T}}{\operatorname{Sp} 1 p^{2}} \\
\text { Dimana : }\end{array}$ \\
\hline & & & & $\begin{array}{l}\text { Keterangan: } \\
\mathrm{p} 1=\text { Jalur tidak langsung pertama yang dilalui } \\
\mathrm{p} 2=\text { Jalur tidak langsung kedua yang dilalui } \\
\text { Sp1p2 = Standard Estimation } \mathrm{p} 1 \text { dan } \mathrm{p} 2\end{array}$ \\
\hline
\end{tabular}

Sumber : Data Diolah, 2020

Hasil perhitungan Sobel Test :

$$
\begin{aligned}
& S p 1 p 2=\sqrt{p 2^{2} S p 1^{2}+p 1^{2} S p 2^{2}+S p 1^{2} S p 2^{2}} \\
& S p 1 p 2=\sqrt{(0.168)^{2}(0,475)^{2}+(1,156)^{2}(0.239)^{2}+(0,475)^{2}(0,239)^{2}} \\
& S p 1 p 2=\sqrt{0,006368+0,076333+0,012888} \\
& S p 1 p 2=\sqrt{0,095589} \\
& \text { Sp1p2 }=0,030917 \\
& t=\frac{p 1 p 2}{S p 1 p 2}
\end{aligned}
$$

$$
\begin{aligned}
& t=\frac{0,194}{0,030917} \\
& t=4,962
\end{aligned}
$$

Berdasarkan Tabel 4 dapat dijelaskan bahwa nilai t-hitung pengaruh pengelolaan dana desa terhadap pembangunan desa sebesar $-4,740<\mathrm{t}$ tabel $210 \alpha 5 \%=1,652$ dengan probabilitas sebesar $0,000<\alpha 5 \%$ berada pada daerah penerimaan H0. Dapat dijustifikasi bahwa secara langsung pengelolaan dana desa memiliki pengaruh yang negatif signifikan terhadap pembangunan desa. Dengan demikian hipotesis 1 (H1) yang menyatakan pengelolaan dana desa berpengaurh positif signifikan terhadap pembangunan desa di Kecamatan Siantar Narumonda tidak dapat diterima atau ditolak.

Berikutnya, nilai t-hitung pengaruh pemberdayaan masyarakat terhadap pembangunan desa sebesar 7,643 > t tabel n 210 $\alpha 5 \%=1.652$ dengan probabilitas sebesar $0,000<\alpha 5 \%$ berada pada daerah penerimaan Ha. Dapat dijustifikasi bahwa pemberdayaan masyarakat secara langsung memiliki pengaruh yang positif signifikan terhadap pembangunan desa. Dengan demikian hipotesis $2(\mathrm{H} 2)$ yang menyatakan pemberdayaan masyarakat berpengaurh positif dan signifikan terhadap pembangunan desa di Kecamatan Siantar Narumonda Kabupaten Toba dapat diterima.

Selanjutnya, t-hitung pengaruh pengelolaan dana desa terhadap pemberdayaan masyarakat sebesar 3,546 > t tabel $210 \alpha 5 \%=$ 1,652 dengan probabilitas sebesar 0,000< $\alpha 5 \%$ berada pada daerah penerimaan Ha. Dapat dijustifikasi bahwa pengelolaan dana desa secara langsung memiliki pengaruh yang positif dan signifikan terhadap pemberdayaan masyarakat. Maka hipotesis 3 (H3) yang menyatakan pengelolaan dana desa berpengaruh positif dan signifikan terhadap pemberdayaan masyarakat di Kecamatan Narumonda Kabupaten Toba dapat diterima.

Terakhir, nilai t-hitung pengaruh pengelolaan dana desa terhadap pembangunan desa melalui pemberdayaan masyarakat sebesar $4,962>\mathrm{t}$ tabel $\mathrm{n} 210 \alpha 5 \%=1,652$, berada pada daerah penerimaan Ha. Dapat dijustifikasi bahwa pengelolaan dana memiliki pengaruh yang positif dan signifikan terhadap pembangunan desa melalui pemberdayaan masyarakat. Dengan demikian hipotesis 4 (H4) yang menyatakan pengelolaan dana desa memiliki pengaruh yang positif signifikan 
terhadap pembangunan desa di Kecamatan Siantar Narumonda Kabupaten Toba melalui pemberdayaan masyarakat dapat diterima.

\section{B. Pembahasan}

Desa merupakan basis kekuatan sosial ekonomi, politik yang perlu mendapat perhatian khusus dan serius dari pemerintah, tidak hanya sebagai objek pembangunan, tetapi harus menjadi subjek pembangunan. Permendesa Pembangunan Daerah Tertinggal, dan Transmigrasi Nomor 16 tahun 2018 tentang perioritas penggunaan dana desa tahun 2019 mengatakan pembangunan desa merupakan suatu upaya yang dilakukan oleh pemerintah desa maupun masyarakatnya untuk meningkatkan kualitas hidup untuk kesejahteraan masyarakat desa. Sebagai bentuk dukungan atas pelaksanaan tugas dan fungsi desa dalam pembangunan desa sesuai dengan kewenangan yang dimiliki, UU Nomor 6 Tahun 2014 memberikan wewenang kepada Pemerintah untuk mengalokasikan Dana Desa yang setiap tahun dianggarkan dalam APBN sebagai salah satu sumber pendapatan desa untuk meningkatkan pelayanan publik di desa, mengentaskan kemiskinan, memajukan perekonomian desa, mengatasi kesenjangan pembangunan antar desa dengan memberdayakan masyarakat desa sebagai subjek dari pembangunan desa. Kessa (2015) salah satu bidang pembangunan desa adalah pemberdayaan masyarakat desa. Dapat dipahami, bahwa berbicara tentang pembangunan desa erat kaitannya dengan dana desa yang dikelola dengan baik dengan melakukan pemberdayaan masyarakat.

Hasil analisis statistik deskpritif yang dilakukan dalam peneltiain ini mendeskripsikan bahwa pembangunan desa di Kecamatan Narumonda Kabupaten Toba telah terlaksana dengan baik, demikian juga dana desa dan pemberdayaan masyarakat juga telah terkelola dan terlaksana dengan baik. Hasil analisis regresi jalur yang dilakukan dalam penelitian ini memberikan bukti empiris bahwa pengelolaan dana desa di Kecamatan Narumonda Kabupaten Toba memiliki pengaruh yang negatif dan signifikan terhadap pembangunan desa. Bukti empiris ini sejalan dengan penelitian Jamaluddin (2018) menemukan pengelolaan dan penggunaan Dana Desa tidak memberi dampak signifikan bagi pertumbuhan pembangunan daerah dan program pembangunan Desa tidak sinkron dengan kebijakan pembangunan Daerah
(RPJM Daerah). Bukti empiris ini juga sekaligus menambah daftar inkonsistensi pengaruh dana desa terhadap pembangunan desa, sebagaimana dihasilkan beberapa penelitian terdahulu yang membuktikan dana desa berpengaruh positif signifikan terhadap pembangunan desa (Muslihah, dkk, 2019, dan Rimawan \& Aryani, 2019).

Lucyanda (2001) mengatakan diperlukan upaya untuk merekonsiliasi ketidakonsistenan hubungan suatu variable dengan mengidentifikasi faktor-faktor kontekstual antar variabel dengan pendekatan kontijensi yang bertindak sebagai variabel moderating ataupun variabel intervening. Sugionyo (2007) mengatakan untuk menguatkan ataupun melemahkan hubungan antara variabel bebas dengan variabel terikat digunakan variable moderating, sedangkan untuk menjembati tidak ada atau tidak sesuainya hubungan antar variabel dengan teori maupun hasil penelitian terdahulu, digunakan variabel intervening. Baron \& Kenny (1986) mengatakan bahwa analisis regresi model mediating atau intervening akan menghasilkan nilai estimasi prediktor dari intervening dan $X$ dinamakan jalur a dan intervening terhadap $\mathrm{Y}$ dinamakan jalur $b$. Kedua nilai estimasi predictor ini diharapkan signifikan. Sedangkan prediksi X terhadap Y dinamakan jalur-c', nilainya diharapkan tidak signifikan.

Pasal 1 ayat 2 Peraturan Pemerintah Nomor 60 Tahun 2014 dan Pasal 2 ayat 1 Peraturan Menteri Dalam Negeri No. 113 Tahun 2014 yang menginstruksikan agar dana desa digunakan untuk meningkatkan kesejahteraan masyarakat dengan memberdayakan lembaga kemasyarakatan setempat merupakan ide yang mendasari dikembangkannya pemberdayaan masyarakat sebagai variabel intervening dalam penelitian ini. Merujuk pada pandangan tersebut, hasil analisis dalam penelitian ini memberikan bukti empiris pengelolaan dana desa berpengaruh positif signifikan terhadap pemberdayaan masyarakat dan pemberdayaan masyarakat juga berpengaruh signifikan terhadap pembangunan desa. Hasil penelitian ini sejalan dengan penelitian Fathony dan Sopian (2019); Bili dan Ra'is (2017); Sofianto (2017); Fatah, dkk (2018) ; Firmansyah, dkk (2020).

Analisis lebih lanjut dalam penelitian ini juga memberikan bukti empiris bahwa pengelolaan dana desa berpengaruh positif signifikan terhadap pembangunan desa 
melalui pemberdayaan masyarakat sebagai variabel intervening. Artinya pengelolaan dana desa akan berkontribusi positif terhadap pembangunan desa, jika dilakukan dengan memberdayakan masyarakat dalam pengelolaan dana desa dan pembangunan desa.

\section{SIMPULAN DAN SARAN}

\section{A. Simpulan}

Berdasarkan hasil analisis dan pembahasan yang dilakukan dalam penelitian ini disimpulkan bahwa secara langsung pengelolaan dana desa berpengaruh negatif signifikan terhadap pembangunan desa di Kecamatan Siantar Narumonda Kabupaten Toba, namun pengelolaan dana desa telah berpengaruh positif signifikan terhadap pemberdayaan masyarakat dan pemberdayaan masyarakat berpengaruh positif signifikan terhadap pembangunan desa. Pengelo-laan dana desa akan berpengaruh positif signifikan jika dimediasi pemberdayaan masyarakat yang baik

\section{B. Saran}

Dari kesimpulan ini, disarankan agar pemerintah desa di Kecamatan Siantar Narumonda Kabupaten Toba lebih concern melakukan pemberdayaan masyarakat melalui pelatihan - pelatihan usaha yang tepat sasaran, pelatihan - pelatihan teknologi yang tepat guna, melakukan penyuluhan - penyuluhan melalui PKK dan karang taruna serta mendorong partisipasi masyarakat didalam mengelola dana desa.

\section{DAFTAR RUJUKAN}

Baron, R. M., \& Kenny, D. A. (1986). The moderator-mediator variable distinction in social psychological research: Conceptual, strategic, and statistical considerations. Journal of Personality and Social Psychology, 51(6), 1173-1182. https://doi.org/10.1037//0022$\underline{3514.51 .6 .1173}$

Bili, Soleman Renda dan Ra'is, Dekki Umamur (2017). Dampak Dana Desa terhadap Pemberdayaan Masyarakat. JISIP: Jurnal Ilmu Sosial dan Ilmu Politik. Vol. 6, No. 3 (2017), hal 38 - 45

Fatah, Zainal, Nihayatus Sholichah dan Ika Devy Pramudiana (2018). Dampak Dana Desa dalam Pembangunan Desa (Studi di Desa Tunjungtirto Kecamatan Singosari
Malang). Asketik Vol. 2 No. 2. hal : 139152.

Fathony, Aditya Achmad dan Sopian, Asep. (2019). Pengaruh Alokasi Dana Desa terhadap Pemberdayaan Masyarakat Dan Peningkatan Kesejahteraan Masyarakat Di Desa Langonsari Kecamatan Pameungpeuk Kabupaten Bandung Akurat. Jurnal Ilmiah Akuntansi, Volume 10, Nomor 3, hal. 41-57.

Ferdinand, A. (2006). Metode Penelitian Manajemen: Pedoman Penelitian untuk Skripsi, Tesis, dan Disertasi Imu Manajemen. Semarang : Universitas Diponegoro.

Firmansyah, Deri, Dwinanto Priyo Susetyo dan Mira Sumira, (2020). Dampak Dana Desa terhadap Pembangunan Desa dan Pemberdayaan Masyarakat Desa pada Desa Cibitung Kecamatan Sagaranten Kabupaten Sukabumi. Jurnal Akuntansi Berkelanjutan Indonesia, Vol. 3, No. 2, Mei 2020, hal $168-181$

Ghozali, Imam. 2013. Aplikasi Analisis Multivariate Dengan Program IBM SPSS 21. Semarang : Badan Penerbit Universitas Diponegoro.

Jamaluddin, Yanhar, Asep Sumaryana, Budiman Rusli \& Rd. Ahmad Buchari. (2018). Analisis Dampak Pengelolaan dan Penggunaan Dana Desa terhadap Pembangunan Daerah. JPPUMA: Jurnal Ilmu Pemerintahan dan Sosial Politik UMA, 6 (1) (2018): 14-24

Kessa, W. (2015). Buku 6: Perencanaan pembangunan desa. Kementerian Desa, Pembangunan Daerah Tertinggal, Dan Transmigrasi Republik Indonesia, 67.

Lucyanda, J. (2001). Hubungan antara anggaran partisipatif dengan kinerja manajerial: peran locus of control sebagai variabel moderating dan motivasi sebagai variabel intervening. Tesis. Program Pascasarjana. Yogyakarta : Universitas Gajah Mada

Mulyanto. (2013). The Model of Index for Massuring the Progress of Rural Development at Autonomy Era in Indonesia: A Pilot Priject in Klaten Regency, Central Java. Paperpresented in 
the $38^{\text {th }}$ Conference of the Federation of ASEAN Economic Associations (FAEA), Singapore, 27th-29th November.

Muslihah, Siti , Siregar, Hilda Octavana dan Sriniyati. (2019). Dampak Alokasi Dana Desa terhadap Pembangunan Dan Kesejahteraan Masyarakat Desa Di Kabupaten Bantul Daerah Istimewa Yogyakarta. Jurnal Akuntansi, Ekonomi dan Manajemen Bisnis, Vol. 7 No. 1, hal. 85-93

Permendesa Pembangunan Daerah Tertinggal, dan Transmigrasi Nomor 16 tahun 2018 tentang perioritas penggunaan dana desa tahun 2019.

Peraturan Menteri Dalam Negeri Nomor 113 Tahun 2016 Tentang pengelolaan Keuangan Desa

Rimawan, M., \& Aryani, F. (2019). Pengaruh Alokasi Dana Desa Terhadap Pertumbuhan Ekonomi, Indek Pembangunan Manusia Serta Kemiskinan Di Kabupaten Bima. Jurnal Ilmiah Akuntansi Dan Humanika. Vol. 9, No. 3. ISSN: 2599-3651, 287-295.
Sofianto, Arif (2017). Kontribusi Dana Desa terhadap Pembangunan dan Pemberdayaan Masyarakat di Kebumen dan Pekalongan. Matra Pembaruan 1 (1) (2017), hal 23-32.

Suharto, Edi. 2014.Membangun Masyarakat Memberdayakan Rakyat. Bandung : PT Refika Aditama.

Undang - Undang No. 32 Tahun 2004 tentang Pemerintahan Daerah

Undang - Undang No 6 Tahun 2016 tentang Desa.

Waluyo, Minto. (2011). Panduan dan Aplikasi Struktural Equation Modelling untuk Aplikasi Model dalam Penelitian Teknik Industri, Psikologi, Sosial dan Manajemen, Jakarta: PT Indeks. 